\title{
MASS MINIATURE RADIOGRAPHY IN THE DETECTION OF HEART DISEASE
}

\author{
BY \\ ALEX MACLEAN AND ALFRED ROGEN · \\ From the Mass Radiography Unit, Glasgow \\ Received November 22, 1948
}

The Glasgow Mass Radiography Unit began operations in the summer of 1944 . Like other such units in the country, its primary intention was the early detection of tuberculous lung disease although it was realized that non-tuberculous conditions and notably heart disease would come within its sphere. The Mass Radiography Sub-Committee of the Minister of Health's Standing Advisory Committee on Tuberculosis, in 1943, laid down standards of cardiovascular abnormalities based on the appearances in full-size chest X-ray films taken after the miniature film had shown an unusual cardiovascular shadow. The abnormal appearances sought were general increase in size of the cardiovascular shadow, increased density of the shadow, displacement of the right cardiac border to the right and of the left border to the left in varying degree, and undue prominence of the large blood vessels.

It was soon observed that the postero-anterior large films gave little information that could not be given by the miniature film. The experienced eye could detect enlargement of the cardiac shadow in the miniature film, making allowance for the greater distortion at a distance of $\mathbf{3 6}$ inches from the X-ray tube focus as against 60 inches. Varying shades of increased density of the cardiovascular shadow itself such as may be caused by the enlarged left auricle of mitral stenosis could also be noted. Accordingly, it became the rule to offer full clinical examination to any person found to have an abnormality of the cardiac shadow on the miniature X-ray film.

During the initial period of our investigation some other observations were made. It was often seen, for example, that prominence of the pulmonary artery shadow did not indicate clinical heart disease. It was, therefore, decided to ask certain questions designed to bring out a history of previous rheumatic infection or of other illness significant in the ætiology of heart disease, and to discover the numbers of people passing through the unit who understood they had some form of heart disease. It was thought that if the X-ray appearances and history could be correlated the findings might be decisive in limiting needless recalls. Also, a history of known heart disease was frequently contradicted by the absence of cardiac abnormality on radiological or clinical examination.

After consideration of the experience of the unit in its first year of operation it was decided that the following groups should be recalled for full clinical examination: (1) patients with a history of rheumatic fever, chorea, or other illness suggestive of acute rheumatism, (2) those with a history of heart disease, and (3) those with abnormality of the cardiovascular shadow in the miniature X-ray film. It was hoped in this way to ensure the detection of cardiac abnormalities in patients unaware of an existing heart lesion with the minimum of inconvenience. This survey was begun in September 1945, and continued till March 1947, when the direct association of the authors in the work of the unit ceased. An account of the findings follows and certain conclusions are drawn; these should enable the unit, while pursuing its primary purpose of detecting tuberculosis in the community, to have a clearer understanding of the significance of the many cardiovascular abnormalities encountered in the day to day work of the unit.

\section{Age Distribution}

Fully two-thirds of those examined were under twenty years of age and rather more than half under fifteen. The reasons for this distribution are the heavy concentration of the unit on the examination of school-leavers, and the choice for survey of industries in which there is a high proportion of young workers because the highest returns of active pulmonary tuberculosis can be expected in these 
groups. As regards heart lesions, the expectation from such a distribution is that congenital disease and lesions due to acute rheumatism will predominate but not lesions the result of degeneration, hypertension, or chronic lung disease. The average recall rate for our purpose was about 49 per thousand; it was rather more in females and rather less in males mainly because of the larger recall rate in the well-represented group of girls under fifteen.

\section{Groups Recalled for Further Study}

Table I shows the relative parts played by history of heart disease, abnormality of the cardiovascular shadow in the X-ray film, and rheumatic history in the recalling of examinees for clinical examination. It brings out that a finding of X-ray abnormality was the commonest single cause for recall, while a history of rheumatic illness and a history of heart disease were much less common causes.

\section{TABLE I}

InCIDENCE of Abnormal X-RAY Heart Shadow AND a History of Heart Disease or Rheumatic FEVER

\begin{tabular}{|c|c|c|}
\hline $\begin{array}{l}\text { Total surveyed (both sexes)... } \\
\text { Recalled for heart investigation }\end{array}$ & $\begin{array}{l}\cdots \\
\cdots\end{array}$ & $\begin{array}{r}34,918 \\
1,703\end{array}$ \\
\hline $\begin{array}{l}\text { History of heart disease } \\
\text { Finding of X-ray abnormality } \\
\text { History of rheumatic illness }\end{array}$ & \begin{tabular}{l|}
$\cdots$ \\
$\cdots$ \\
$\cdots$
\end{tabular} & $\begin{array}{l}31 \% \\
66 \% \\
44 \%\end{array}$ \\
\hline $\begin{array}{l}\text { History of heart disease + findir } \\
\text { of X-ray abnormality. } \\
\text { History of heart disease + histo } \\
\text { of rheumatic illness. } \\
\text { Finding of X-ray abnormality } \\
\text { rheumatic illness. }\end{array}$ & & $\begin{array}{l}11 \% \\
19 \% \\
19 \%\end{array}$ \\
\hline $\begin{array}{l}\text { History of heart disease }+ \text { finding } \\
\text { X-ray abnormality }+ \text { history } \\
\text { rheumatic illness. }\end{array}$ & $\begin{array}{l}\text { g of } \\
\text { of }\end{array}$ & $7 \%$ \\
\hline
\end{tabular}

The percentage figures refer to the number recalled.

It was also found that when a history of heart disease was not elicited, a finding of X-ray abnormality was a much more common cause for recall than a history of rheumatic illness. The reverse was the case in the group in which a history of heart disease was obtained.

\section{The Value of a History of Rheumatic ILLNESS}

Questions were put by trained clerical staff at the time of the miniature film examination to elicit a history of one or more attacks of rheumatic fever, one or more attacks of chorea or of other illness consistent with acute rheumatism. A preliminary investigation had suggested that histories of sore throat, blood-poisoning and scarlet fever were too common to be of value although if any one of these was accompanied by arthritis or muscular pains some importance might be attached to it. Such rheumatic symptoms are represented in this series under the heading of " other rheumatic manifestations." All histories were closely checked by the medical examiner at the time of the clinical examination and almost invariably found to be correct.

Table II shows the relative frequency of the various types and grades of rheumatic illness in this group. A single attack of rheumatic fever was the most frequent finding; other rheumatic manifestations were less common; chorea was relatively rare. There was no great difference between the sexes except that chorea was more common among the females.

\section{TABLE II}

The InCidence of the Various Grades of Rheumatic INFECTION IN THE GROUP RECALLED ON THIS ACCOUNT

\begin{tabular}{l|r|r|r}
\hline & Male & Female & $\begin{array}{r}\text { Both } \\
\text { sexes }\end{array}$ \\
\hline $\begin{array}{l}\text { History of rheumatic fever once } \\
\text { History of rheumatic fever } \\
\text { twice or more. }\end{array}$ & $\begin{array}{r}219 \\
\text { History of chorea once }\end{array}$ & 177 & 396 \\
$\begin{array}{l}\text { History of chorea twice or } \\
\text { more. }\end{array}$ & 17 & 37 & 71 \\
$\begin{array}{l}\text { History of rheumatic fever and } \\
\text { chorea. }\end{array}$ & 13 & 7 & 20 \\
$\begin{array}{l}\text { History of other rheumatic } \\
\text { manifestations. }\end{array}$ & 57 & 143 & 200 \\
\hline Totals .. & 343 & 406 & 749 \\
\hline
\end{tabular}

Table III shows the relationship in the whole series. between a history of rheumatic infection and the clinical findings. It brings out the greater frequency with which acquired heart disease is associated with multiple attacks of rheumatic fever or chorea and the relative unimportance in respect of organic disease of the group of " other rheumatic manifestations." Equally noticeable is the frequency of normal findings when there is a history of a single attack of rheumatic fever.

In patients giving a history of rheumatic infection but not giving a history of heart disease there are few instances of acquired heart disease (21 out of 423 examined) suggesting that in most cases when acute rheumatism causes heart disease that fact is known to the patient. On the other hand, in patients giving a history of rheumatic infection and a history of heart disease the opposite obtains, namely, a high incidence of organic heart disease, and this is 


\section{TABLE III}

SHOWS HOW a History of RHeUMATIC INFECTION Is Related to (a) NoRMAL Findings, $(b)$ NoNSIGNIFICANT FINDINGS, AND (c) EVIDENCE OF ORGANIC DISEASE

\begin{tabular}{|c|c|c|c|}
\hline & Normal & $\begin{array}{l}\text { Non- } \\
\text { signi- } \\
\text { ficant } \\
\text { findings }\end{array}$ & $\begin{array}{l}\text { Organic } \\
\text { disease }\end{array}$ \\
\hline $\begin{array}{l}\text { History of rheumatic } \\
\text { fever once. }\end{array}$ & $234(54 \%)$ & $80(52 \%)$ & $76(52 \%)$ \\
\hline $\begin{array}{l}\text { History of rheumatic } \\
\text { fever twice or more. }\end{array}$ & $23(5 \%)$ & $12(8 \%)$ & $32(22 \%)$ \\
\hline $\begin{array}{l}\text { History of chorea once. } \\
\text { History of chorea twice } \\
\text { or more. }\end{array}$ & $\begin{array}{r}30(7 \%) \\
4(1 \%)\end{array}$ & $\begin{array}{r}11(7 \%) \\
1(1 \%)\end{array}$ & $\begin{array}{r}12(8 \%) \\
3(2 \%)\end{array}$ \\
\hline $\begin{array}{l}\text { History of chorea and } \\
\text { rheumatic fever. }\end{array}$ & $9(2 \%)$ & $3(2 \%)$ & $8(5 \%)$ \\
\hline $\begin{array}{l}\text { History of other rheu- } \\
\text { matic illness. }\end{array}$ & $130(30 \%)$ & $46(30 \%)$ & $16(11 \%)$ \\
\hline Total & 430 & 153 & 147 \\
\hline
\end{tabular}

again most marked where there is a history of multiple rheumatic infection. Six cases of congenital heart disease and thirteen of hypertension were also discovered.

The group of non-significant findings such as innocent mitral systolic murmurs, or a split first sound at the apex would be expected to run parallel with the group of normal findings if it had no relation to rheumatic illness; if it had such a relationship it should reflect the results in the group of organic disease findings. Table III suggests that it has closer affinities with the normal group than with the group of heart disease.

\section{The X-RAY Appearances}

The shadows on the $35 \mathrm{~mm}$. film, being photographs of the appearances on a fluorescent screen placed at a distance of 36 inches from the focus of the X-ray tube, are somewhat distorted. Those placed to the periphery of the photograph are larger than those more centrally placed in comparison with the actual structures within the chest; and also in respect of the fact that tissues within the chest which are close to the X-ray focus, and therefore far from the fluorescent screen, cast larger images than those farther from the X-ray focus. Thus in ordinary postero-anterior films in which the patient faces the fluorescent screen with his back to the $\mathrm{X}$-ray tube the shadow cast by the spine or a posteriorly placed tumour will be relatively broader than that of the aorta and that in turn relatively larger than the shadow of the heart or an anteriorly placed tumour. Further, cardiac enlargement will be emphasized and actual enlargement of the heart will never be quite so much as the shadow on the $35 \mathrm{~mm}$. film would suggest. Another point is that prominences posterior to the heart will be emphasized at the expense of the shadows cast by the lateral borders of the heart so that the pear-shaped increase of density in the heart shadow cast by the hypertrophied left auricle in mitral stenosis will be more obvious than in a film taken at a greater distance than 36 inches.

Slight scoliosis may simulate cardiac enlargement in a miniature film and so may slight rotation of the patient. Films showing evidence of such deformity or of rotation were not included in this series. Table IV shows the frequency with which various radiological abnormalities were found.

\section{TABLE IV}

Frequency of X-Ray Abnormalities in the Series

\begin{tabular}{|c|c|c|c|}
\hline & Male & Female & $\begin{array}{l}\text { Both } \\
\text { sexes }\end{array}$ \\
\hline $\begin{array}{l}\text { General cardiac enlargement. } \\
\text { Prominence of pulmonary } \\
\text { artery. }\end{array}$ & $\begin{array}{l}320 \\
182\end{array}$ & $\begin{array}{l}299 \\
277\end{array}$ & $\begin{array}{l}619 \\
459\end{array}$ \\
\hline $\begin{array}{l}\text { Straightening of left heart } \\
\text { border. }\end{array}$ & 41 & 74 & 115 \\
\hline $\begin{array}{l}\text { Unfolding of aorta } \\
\text { Broadening of base of heart. }\end{array}$ & $\begin{array}{l}42 \\
18\end{array}$ & $\begin{array}{l}45 \\
50\end{array}$ & $\begin{array}{l}87 \\
68\end{array}$ \\
\hline $\begin{array}{l}\text { Prominent conus } \\
\text { Dextrocardia .. }\end{array}$ & 65 & 28 & 93 \\
\hline Dextrocardia & 3 & 2 & 5 \\
\hline
\end{tabular}

Table $\mathrm{V}$ shows the relationship between radiological general cardiac enlargement, irrespective of degree, and the clinical findings. It shows that in only a twelfth of the cases of cardiac enlargement without history of heart disease is there evidence of heart disease, and even where there is a history of heart disease the presence of a heart lesion in such cases is confirmed only in rather more than half the cases (about two-thirds of females, less than half of males).

The relationship between prominence of the pulmonary artery shadow in the miniature X-ray film and the clinical findings is shown in Table $V$. The pulmonary artery was judged to be prominent if it overlapped a line joining the aortic bulb and the left heart border at ventricular level. The Table shows that few cases with prominence of the pulmonary artery have an actual cardiac lesion; even in the group with a history of heart disease less than half have been confirmed as in fact having heart disease. The same conclusion can be drawn when the clinical findings are related to straightening of the left heart border in the X-ray film. 
TABLE V

Relationship of X-RAY aNd Clinical Findings

\begin{tabular}{|c|c|c|c|c|c|c|}
\hline & Normal & $\begin{array}{l}\text { Non- } \\
\text { significant }\end{array}$ & Organic & Congenital & Hypertensive & Total \\
\hline \multicolumn{7}{|c|}{ Radiological Cardiac Enlargement } \\
\hline $\begin{array}{l}\text { No history of heart disease .. } \\
\text { History of heart disease }\end{array}$ & $\begin{array}{r}297(72 \%) \\
29(28 \%)\end{array}$ & $\begin{array}{l}83(20 \%) \\
14(14 \%)\end{array}$ & $\begin{array}{l}24(6 \%) \\
55(53 \%)\end{array}$ & $\begin{array}{l}4(1 \%) \\
3(3 \%)\end{array}$ & $\begin{array}{l}5(1 \%) \\
2(2 \%)\end{array}$ & $\begin{array}{l}413 \\
103\end{array}$ \\
\hline
\end{tabular}

Prominence of the Pulmonary Artery Shadow

\begin{tabular}{ll|r|r|r|r|r|r}
\hline $\begin{array}{l}\text { No history of heart disease } \\
\text { History of heart disease }\end{array}$ & \begin{tabular}{rl|l}
$305(73 \%)$ \\
$10(24 \%)$
\end{tabular} & $\begin{array}{l}96(23 \%) \\
13(32 \%)\end{array}$ & $14(3 \%)$ & $3(1 \% \%)$ & $2(5 \%)$ & - & 418 \\
\hline
\end{tabular}

Prominence of Conus

\begin{tabular}{ll|c|r|r|l|l|l}
\hline $\begin{array}{l}\text { No history of heart disease } \\
\text { History of heart disease }\end{array}$ & $\begin{array}{c}24(52 \%) \\
1(4 \%)\end{array}$ & $\begin{array}{r}15(33 \%) \\
3(14 \%)\end{array}$ & $\begin{array}{r}6(13 \%) \\
\hline(82 \%)\end{array}$ & $\begin{array}{l}1(2 \%) \\
0\end{array}$ & - & $\begin{array}{l}46 \\
22\end{array}$ \\
\hline
\end{tabular}

When broadening of the base of the heart shadow (i.e. the distance between the right border of the superior vena cava and ascending aorta on the right and the descending part of the aortic arch on the left) is related to the clinical findings, it is found that if it is present in association with heart disease the fact of the latter is known to the patient. No case of organic heart disease was found in this group in the absence of a history of heart disease. The same conclusion could be drawn when clinical findings were correlated with unfolding of the aorta, including prominence of the aortic bulb; as might be expected, hypertension was a more common finding in this group.

Table $V$ also shows the relationship between prominence of the pulmonary conus and the clinical findings. When there is clinical evidence of disease and a prominent conus is noted in the X-ray film, the patient is usually already aware that he has heart disease. At the same time, the frequency of discovery of unsuspected organic disease was higher than with prominence of the pulmonary artery.

\section{The Clinical Examination}

The examination of 529 people who believed they had heart disease, revealed no evidence of this in 340 (64 per cent). Table VI shows this and also the incidence of cardiac lesions at different age groups. In almost all the cases the examination was entirely clinical, the findings in the erect position, in the supine position, on the left side, and after exertion being correlated. The blood pressure was taken if it was considered relevant. Only in exceptional cases were further aids to diagnosis, such as radiography in the oblique

TABLE VI

Age Distribution of Examinees and Incidence of Cardiac Lesions in those with a History OF HeART Disease

\begin{tabular}{l|c|c|c|c|c|c|c|c|c}
\hline & \multicolumn{7}{|c}{ Age in Years } \\
\cline { 2 - 9 } & Up to 14 & $15-19$ & $20-24$ & $25-29$ & $30-39$ & $40-49$ & $50-59$ & $\begin{array}{c}60 \text { and } \\
\text { over }\end{array}$ & Total \\
\hline $\begin{array}{c}\text { Total number (A) (to nearest } \\
\text { hundred). }\end{array}$ & 189 & 46 & 30 & 20 & 28 & 22 & 11 & 3 & 349 \\
\hline $\begin{array}{l}\text { Number with history of heart } \\
\text { disease (B). }\end{array}$ & 247 & 61 & 35 & 28 & 69 & 38 & 41 & 10 & 529 \\
$\begin{array}{c}\text { Percentage of (B) with heart } \\
\text { disease. }\end{array}$ & 33 & 34 & 51 & 43 & 38 & 34 & 37 & 20 & 36 \\
\hline
\end{tabular}


positions or following a barium swallow, electrocardiography or sphygmography, employed as it was the intention to interfere as little as possible with the routine of the school child or worker. Patients were on occasions admitted to hospital for diagnostic purposes or with a view to treatment.

The main clinical findings have been sufficiently considered in the preceding sections of this paper. It remains to discuss first the group of what has been labelled non-significant findings, and secondly, to give the details of our findings in the "organic disease" group. Under the heading of nonsignificant findings are such final clinical diagnoses as split mitral first sounds, innocent mitral systolic murmurs, split pulmonary second sounds and pulmonary systolic murmurs.

The total incidence of innocent mitral systolic murmurs, pulmonary systolic murmurs and split mitral first sounds, is shown in Table VII. Of the 1703 cases 798 were males, and 905 females.

Split mitral first sound. This is probably most commonly confused with the presystolic murmur of mitral stenosis. A split first sound was diagnosed in this series when no diastolic element was brought out by change in posture or by exercise; the sound was usually made more evident by exercise and was best heard at the end of expiration when the breath was held. As long as its possibility is kept in mind the very different character of the first part of the sound is not likely to be mistaken for a short presystolic murmur. In our series it was not commonly associated with X-ray abnormalities. Its incidence was 10 per cent in the absence of X-ray abnormality, and 7 per cent in association with such abnormality.
It was no more common in patients giving a history of rheumatic fever than in those without such a history; the incidence was 8 per cent in both groups. These figures merit the belief that rheumatic infection played no part in the production of the findings. We are satisfied that the finding is not a significant one and that its incidence in such a series as this is as high as 8 per cent.

Innocent mitral systolic murmurs. The certain diagnosis of this group of murmurs is always difficult. Where a murmur did not have the properties possessed by the "organic murmurs," of loudness, propagation, and encroachment on the first sound, it was considered in the light of Evans' classification of innocent murmurs (Evans, 1947) and its relation to the patient's posture, and its position in the cardiac cycle, was studied. Phonocardiography was not used.

The incidence of the finding was between 5 and 6 per cent in both sexes. Its frequency was 5 per cent in the absence of a history of rheumatic infection and 6 per cent when there was such a history -figures so close as to show that rheumatic fever played no part in its causation. Among the group who had no reason to believe they had heart disease the innocent mitral murmur was found in rather less than 4 per cent whereas it was found in more than 9 per cent of those who believed they had heart disease. The innocent murmur was found in only 4 per cent of those with and in 8 per cent of those without, radiological abnormality. Stress should be laid, therefore, on the comparatively common incidence of this murmur, its frequent confusion with the "organic murmur," and the absence of

\section{TABLE VII}

Shows the Incidence of Mitral Systolic Murmurs, Pulmonary Systolic Murmurs and Split Mitral First Sounds IN THE PResent Series

\begin{tabular}{|c|c|c|c|c|c|c|c|c|c|c|c|c|}
\hline \multirow{3}{*}{$\begin{array}{l}\text { History of rheumatic } \\
\text { infection. } \\
\begin{array}{l}\text { History of known } \\
\text { heart disease. }\end{array}\end{array}$} & \multicolumn{4}{|c|}{ None } & \multicolumn{4}{|c|}{ Rheumatic fever } & \multicolumn{4}{|c|}{$\begin{array}{l}\text { Other rheumatic mani- } \\
\text { festations }\end{array}$} \\
\hline & \multicolumn{2}{|c|}{ No } & \multicolumn{2}{|c|}{ Yes } & \multicolumn{2}{|c|}{ No } & \multicolumn{2}{|c|}{ Yes } & \multicolumn{2}{|c|}{ No } & \multicolumn{2}{|c|}{ Yes } \\
\hline & Absent & $\begin{array}{l}\text { Pre- } \\
\text { sent }\end{array}$ & Absent & $\begin{array}{l}\text { Pre- } \\
\text { sent }\end{array}$ & Absent & $\begin{array}{l}\text { Pre- } \\
\text { sent }\end{array}$ & Absent & $\begin{array}{l}\text { Pre- } \\
\text { sent }\end{array}$ & Absent & $\begin{array}{l}\text { Pre- } \\
\text { sent }\end{array}$ & Absent & $\begin{array}{l}\text { Pre- } \\
\text { sent }\end{array}$ \\
\hline X-ray abnormality. & 22 & 729 & 130 & 73 & 200 & 85 & 178 & 86 & 17 & 121 & 33 & 29 \\
\hline Total mitral systolic. & 4 & 24 & 13 & 7 & 9 & 3 & 19 & 7 & 0 & 5 & 3 & 1 \\
\hline $\begin{array}{l}\text { Total pulmonary } \\
\text { systolic. }\end{array}$ & 3 & 76 & 7 & 8 & 13 & 5 & 16 & 4 & 1 & 18 & 2 & 2 \\
\hline $\begin{array}{l}\text { Total split mitral } \\
\text { first sound. }\end{array}$ & 3 & 52 & 14 & 7 & 18 & 3 & 20 & 5 & 1 & 12 & 1 & 1 \\
\hline
\end{tabular}


correlation with a history of rheumatic fever or X-ray abnormality.

Split pulmonary second sound. This finding is not uncommon in mitral stenosis. A split pulmonary second sound was found frequently in the series of 1703 cases examined and no significance could be attached to the finding at the time of examination. These cases are being followed up. The exact numbers in the series cannot be given because the great frequency of the finding was not fully appreciated at the start of the investigation and it was not particularly noted at first. Latterly, the prevalence of this sign in the absence of any discoverable clinical abnormality became obvious, and more recent observations have only served to confirm our opinion that it is particularly common and apparently without clinical significance. It was about twice as common in males and the incidence was comparable whether there was or was not an $\mathrm{X}$-ray abnormality. It was almost twice as common when there was a "rheumatic history" and fully twice as common in those who understood they had heart disease.

Pulmonary systolic murmur. The murmur was found alone, or in combination with other nonsignificant findings, in 155 cases ( 9 per cent). No account is taken here of those cases in which it was heard in association with mitral stenosis. It was more common in females-almost 13 per cent as against 5 per cent in males. Rheumatic infection was not concerned in its production -8 per cent as against 10 per cent in the absence of such a history. While it was found in a considerable proportion of cases understood to have heart disease, fully 7 per cent in a total of 529, yet it was found more commonly among those who had no reason to believe that they had a cardiac abnormality (10 per cent of 1174 examined). It was more common in the presence of radiological abnormality than in its absence; the abnormality reported in almost every case was enlargement of the pulmonary artery, resulting in straightening of the left heart border or actual prominence of the artery beyond that line. Further, it was most common in the younger agegroups, e.g. of the 155 cases 110 were under 15 years. It was comparatively rare in adult life. The probable explanation of the presence of the murmur is that the artery is dilated beyond a normal pulmonary ring, and its more common occurrence in the younger age-groups may be associated with the greater distensibility of the soft and resilient artery in adolescence. Increase in the blood flow in the pulmonary artery as brought about by exercise accentuates a murmur already there and often brings out a murmur not heard previously. The importance and significance of this murmur must be recognized. Prominence of the pulmonary artery was much more commonly associated with it than with organic mitral disease.

\section{Organic Disease}

Of the 1703 cases examined, 220 (just over 12 per cent) were found to have organic heart disease (Table VI). The bulk of these had mitral valve disease, a few had aortic valve disease, and the remainder were found to have auricular fibrillation, coronary occlusion, or myocarditis. Mitral valve disease was found in 185 (11 per cent); and aortic valve disease in 13 (less than one per cent); three patients had both aortic and mitral valve disease.

The incidence of normal findings among those believed to have heart disease has been stressed, but it should be noted that a diagnosis of organic valve disease was occasionally made for the first time in the course of the routine work of the mass radiography unit. Mitral valve disease was diagnosed in 41 cases and aortic valve disease in 3 . Of the 41 with mitral disease 21 gave a history of previous rheumatic infection. Therefore, only 20 , all of whom had abnormal X-ray findings, would have been found in the series relying solely on the lead given by the radiological picture. One only of the three patients with aortic disease was discovered because of X-ray abnormalities (in the other two there was a history of rheumatic infection). Twentyone cases, therefore, of organic valve disease were discovered as the result of abnormal radiological appearances in 34,918 routine X-rays of the chest.

\section{SUMmaRY AND CONCLUSIONS}

In the course of the routine working of the Mass Radiography Unit in Glasgow many abnormal cardiovascular shadows were encountered. Of these the most common were general cardiac enlargement, prominence of the pulmonary artery, straightening of the left heart border, unfolding of the aorta, broadening of the base of the heart, prominence of the pulmonary conus, and dextrocardia. In an effort to limit needless recalls an attempt was made to correlate the various radiological abnormalities with a history of previous rheumatic infection or known heart disease.

Of 34,918 cases $\mathrm{X}$-rayed by the unit in the course of the investigation, fully 67 per cent were under 20 years of age. Altogether 798 males ( 4.3 per cent) and 905 females $(5.5$ per cent) were recalled. Of the 1703 recalled the commonest cause of recall was an unusual X-ray picture; a history of previous rheumatic infection was a less common cause of recall, and least common was a history of known heart disease. All three reasons for recall were present in 115 cases (almost 7 per cent). 
A history of one attack of rheumatic fever was associated with a finding of organic heart disease in, roughly, only one in five cases: two or more attacks resulted in clinical evidence of disease in rather less than half the cases giving such a history. This is a low incidence, but it must be realized that no strict check could be made on the accuracy of the history of rheumatic fever; many comparatively minor febrile illnesses masquerade under this heading. Although the numbers were smaller, it was found that one attack of chorea resulted in organic heart disease slightly more often than did one attack of rheumatic fever. Patients with a history of previous rheumatic infection and found to have heart disease mostly knew of it; apart from examples of hypertension only 23 cases were found to have heart disease not previously known to them-21 with organic valve disease, 2 with congenital heart disease.

Radiological cardiac enlargement was associated with organic heart disease in 93 cases (out of 516 in whom this X-ray finding was reported). Prominence of the pulmonary artery shadow was not a common cause of heart disease being brought to light for the first time; only 14 cases of acquired and 3 of congenital disease were found in this way out of 418 examined. Prominence of the conus, though less frequently diagnosed in the film, was more likely to be supported by clinical evidence of organic disease, than was a prominent pulmonary artery.
An outstanding finding was that no evidence of disease was found in 340 out of 529 patients who believed they had heart disease (64 per cent).

The frequency of non-significant findings such as split mitral first sounds, mitral systolic murmurs, split pulmonary second sounds, and pulmonary systolic murmurs is noted and their relationship with radiological abnormalities and a history of rheumatic infection described.

Of the 1703 cases examined 220 were found to have acquired organic heart disease; of these 185 had mitral disease, 13 aortic disease, and 3 both mitral and aortic disease. Only 41 cases of mitral disease and 3 cases of aortic disease were found in which the disability had been unknown to the patient. Of these, 20 with mitral disease and one with aortic disease were referred solely on account of the radiological findings. Thus only 21 cases of organic valve disease were diagnosed for the first time in 34,918 routine X-rays of the chest.

In conclusion the common radiological patterns sometimes thought to be suggestive of heart disease are not, as a rule, associated with clinical signs of disease. Such patterns by themselves do not suffice for a diagnosis of heart disease.

\section{REFERENCE}

Evans, W. (1947). Brit. Heart J., 9, 1. 